\title{
Dampak Promosi dan Citra Merek Terhadap Keputusan Konsumen Membeli Sepeda Motor Merek Honda di PT Capella Dinamik Nusantara Pekanbaru
}

\author{
NURUL SUKRIANI \\ Sekolah Tinggi Ilmu Ekonomi Persada Bunda \\ Jl. Diponegoro No. 43 Pekanbaru-Riau, Telp. (0761) - 40218 \\ E-mail : nurulhijab85@gmail.com
}

\begin{abstract}
This research was conducted for PT. Capella Dinamik Nusantara Pekanbaru, using the independent variable, to find out its influence on the purchase decision of the Honda brand motorcycle. Population in this research were all consumers who bought Honda brand motorcycles through official Honda dealers in Pekanbaru, namely PT. Capella Dinamik Nusantara directed 19,853 people, and this sample was 100 people, using accidental random sampling technique that is by giving questionnaires to consumers of Honda motorbike buyers at PT Capella Dinamik Nusantara which were met by researchers. The data was collected by questionnaire method by filling the conditions directly with the respondents. Analysis technique used is multiple linear regression which is operated through the SPSS 16 for Windows program. The results showed that simultaneous and partial promotion variables and a significant analysis of the purchasing decisions of Honda brand motorcycles for consumers of PT Capella Dinamik Nusantara Pekanbaru
\end{abstract}

Keywords: Promotion, Brand Image, Purchase Decision

Pada saat ini bisnis otomotif, khusus nya sepeda motor mengalami persaingan yang sangat ketat, para pelaku bisnis sepeda motor berlomba-lomba melakukan berbagai macam inovasi tentunya dengan tujuan untuk menarik minat para konsumen sepeda motor di Indonesia. Berbagai macam merek sepeda motor pun bermunculan di Indonesia seperti Honda, Yamaha, Kawasaki, TVS, Suzuki, dan terdapat beragam merek sepeda motor lainnya lagi yang bisa di katakan pendatang baru di dunia otomotif khusus nya sepeda motor di Indonesia. Kehadiran mereka berusaha untuk menarik minat beli masyarakat terhadap produk mereka.

Merek merupakan faktor penting dalam persaingan dan menjadi aset perusahaan yang bernilai, karena merek pada saat ini juga menjadi pertimbangan konsumen dalam memilih sepeda motor. Jika perusahaan memiliki citra merek yang kuat dari perusahaannya, maka merek yang dimiliki perusahaan tersebut dapat memberikan keuntungan jangka panjang bagi perusahaan dari aspek produk, penjualan, dan perusahaan. Citra merek sangat penting bagi sebuah perusahaan dikarenakan citra merek dapat meningkatkan preferensi konsumen terhadap sebuah merek. Keputusan pembelian konsumen dipengaruhi oleh perilaku konsumen itu sendiri. Dalam melakukan keputusan pembelian, tentunya dibutuhkan keyakinan dan rasa percaya diri yang kuat dari pelanggan. Sikap yang positif atas merek dapat mendorong keputusan pembelian oleh konsumen dapat terlaksana. Kebutuhan akan sepeda motor saat ini bukan hanya untuk kebutuhan dan keinginan saja, akan tetapi karena disertai perbedaan pendapatan, pendidikan, pengalaman kerja, sikap dan motivasi konsumen menimbulkan perilaku konsumen yang juga membutuhkan prestise dalam pembelian produk sepeda motor.

Meskipun ada beberapa merek sepeda motor yang terdapat di Pekanbaru, akan tetapi hanya dua yang menguasai pasar sepeda motor di Pekanbaru dalam porsi yang sangat besar dan terus 
bersaing, yaitu sepeda motor merek Honda dan Yamaha. Berikut ini di tampilkan data market share beberapa merek sepeda motor di Pekanbaru :

Tabel Market Share Sepeda Motor di Pekanbaru pada Tahun 2015-2017

\begin{tabular}{|c|l|c|c|c|}
\hline No & Merek & $\begin{array}{c}\mathbf{2 0 1 5} \\
(\boldsymbol{\%})\end{array}$ & $\begin{array}{c}\mathbf{2 0 1 6} \\
(\mathbf{\%})\end{array}$ & $\begin{array}{c}\mathbf{2 0 1 7} \\
(\mathbf{\%})\end{array}$ \\
\hline 1 & Honda & 65,2 & 69,7 & 74,4 \\
\hline 2 & Yamaha & 28,4 & 24,3 & 20,6 \\
\hline 3 & Suzuki & 4,1 & 2,5 & 1,9 \\
\hline 4 & Kawasaki & 2,3 & 3,2 & 2,4 \\
\hline 5 & Piaggio & 0 & 0,3 & 0,6 \\
\hline 6 & Lainnya & 0 & 0 & 0,2 \\
\hline
\end{tabular}

Sumber : Marketing Division PT Capella Dinamik Nusantara

Berdasarkan tabel di atas dapat disimpulkan bahwa pemakai sepeda motor merek lain banyak yang berpindah ke merek Honda, hal ini tentu saja membuktikan bahwa Citra Merek sepeda motor Honda semakin kuat di masyarakat Pekanbaru dan menjadi pilihan pertama setiap kali ingin membeli sepeda motor. PT Capella Dinamik Nusantara merupakan distributor resmi kendaraan sepeda motor Honda untuk kawasan Pekanbaru. Perusahaan ini menyediakan pelayanan baik penjualan sepeda motor, suku cadang dan servis. Dalam hal ini PT Capella Dinamik Nusantara berusaha menjadi perusahaan distributor yang mampu bersaing dengan kompetitornya. Salah satu caranya yaitu melalui meningkatkan kualitas citra merek dari produk sepeda motor yang mereka miliki. Citra merek yang selalu diingat oleh para konsumen adalah cenderung merek-merek yang terkenal, karena mereka berpikir merek yang sudah memiliki citra yang baik, lebih pantas di beli karena adanya jaminan penuh terhadap kualitas, kehandalan, kesesuaian dan pelayanan. Konsumen berpendapat bahwa semakin baik citra merek maka semakin mudah pula konsumen dalam melakukan keputusan pembelian terhadap produk tersebut. Berikut ditampilkan keputusan pembelian sepeda motor merek
Honda, yang diukur melalui realisasai dan target penjualan :

Tabel Target dan Realisasi Penjualan PT Capella Dinamik Nusantara di Pekanbaru 2013-2017

\begin{tabular}{|c|c|c|c|c|c|}
\hline $\begin{array}{l}\mathbf{N} \\
\mathbf{0}\end{array}$ & $\begin{array}{c}\text { Tahu } \\
\text { n }\end{array}$ & $\begin{array}{c}\text { Target } \\
\text { Penjua } \\
\text { lan } \\
\text { (Unit) }\end{array}$ & $\begin{array}{c}\text { Realisa } \\
\text { si } \\
\text { Penjua } \\
\text { lan } \\
\text { (Unit) }\end{array}$ & $\begin{array}{c}\text { Perse } \\
\text { ntase } \\
\text { Penca } \\
\text { paian } \\
(\%)\end{array}$ & $\begin{array}{c}\text { Jumla } \\
\text { h } \\
\text { Konsu } \\
\text { men } \\
\text { (Oran } \\
\text { g) } \\
\end{array}$ \\
\hline 1 & 2013 & 22.549 & 24.554 & 108,9 & 22.099 \\
\hline 2 & 2014 & 24.804 & 23.951 & 96,6 & 21.181 \\
\hline 3 & 2015 & 26.284 & 23.534 & 89,5 & 21.309 \\
\hline 4 & 2016 & 29.740 & 23.202 & 78,0 & 21.171 \\
\hline 5 & 2017 & 31.400 & 22.854 & 72,8 & 19.853 \\
\hline
\end{tabular}

Sumber : Marketing Division PT Capella Dinamik Nusantara

Berdasarkan tabel tersebut dapat dilihat bahwa penjualan PT Capella Dinamik Nusantara di Pekanbaru telah mengalami penurunan. Penjualan pada tahun 2013 mencapai $108,9 \%$ yang merupakan pencapaian terbaik dalam 5 tahun ini. Akan tetapi realisasi penjualan pada tahun berikutnya yaitu 2014 mengalami penurunan sebesar $12,3 \%$. Kemudian dari tahun 2015 dan 2016 terus mengalami penurunan masing-masing sebesar $7,1 \%$ dan $11.5 \%$. Dan pada tahun 2017 mencapai titik terendah yaitu $72,8 \%$ dan turun dari tahun 2016 sebesar 5,2\%.

Selain terus meningkatkan kualitas merek nya di mata konsumen, PT Capella Dinamik Nusantara juga meningkatkan kegiatan promosi untuk dapat semakin memperbesar minat konsumen untuk melakukan pembelian sepeda motor merek Honda khusus nya di Pekanbaru. Beberapa kegiatan promosi yang mereka lakukan adalah periklanan pada media, brosur, surat kabar, majalah, dan televisi lokal. Perusahaan juga melakukan berbagai macam promosi lainnya seperti pemberian diskon langsung kepada konsumen, pameran, potongan biaya administrasi.

PT. Capella Dinamik Nusantara juga memiliki pilihan type dan model sepeda motor merek Honda yang lengkap, 
jaringan purna jual yang siap untuk memberikan pelayanan servis yang terbaik kepada konsumen dengan tenaga mekanik yang terlatih dan menempuh pendidikan formal sebagai mekanik Honda, suku cadang asli Honda juga mudah didapatkan di Outlet / Part Shop. Dengan berbagai macam keunggulan yang di miliki oleh sepeda motor merek Honda perusahaan berharap produk mereka tetap menjadi produk sepeda motor yang paling banyak diminati oleh konsumen Indonesia.

Peter dan Olson dalam Sangadji menjelaskan (2013:332), keputusan pembelian adalah proses pemecahan masalah yang diarahkan pada sasaran. Menurut Setiadi dalam Fahmi (2016:57) mendefinisikan bahwa keputusan konsumen adalah suatu proses pengintegrasian yang mengkombinasikan pengetahuan untuk mengevaluasi dua perilaku alternatif atau lebih, dan memilih salah satu di antaranya. Hasil dari proses pengintergrasian ini adalah suatu pilihan yang disajikan secara kognitif sebagai keinginan berperilaku. Konsumen akan selektif dalam membeli produk atau jasa, akan melakukan beberapa hal sebelum memutuskan untuk membeli. Hal ini dilakukan agar konsumen tidak salah membeli produk yang akan digunakan untuk memenuhi kebutuhan dan menyelesaikan masalah yang dihadapinya.

Menurut Engel et all dalam Sangadji (2013 : 334) terdapat beberapa tahapan dalam menganalisis perilaku konsumen dalam pengambilan keputusan pembelian yaitu : Pengenalan akan kebutuhan konsumen, Mengumpulkan berbagai macam informasi, Melakukan evaluasi alternative, Melakukan Pembelian, Melakukan Penilaian

Keputusan pembelian yang dilakukan konsumen merupakan hasil akhir dari pertimbangan konsumen sebelum membeli produk. Keputusan konsumen dapat diukur dengan beberapa alat ukur. Dalam Kotler \& Keller (2009:178), indikator keputusan pembelian terdiri dari pilihan produk, pilihan merek, pilihan penyalur, jumlah pembelian, waktu pembelian. Menurut Sunyoto (2018:283) menyatakan bahwa keputusan pembelian konsumen sebenarnya merupakan sejumlah keputusan yang berkaitan dengan berbagai macam hal - hal yang berkaitan dengan :Jenis produk, Bentuk produk, Merek, Penjualan, Jumlah produk, Waktu pembelian dan Cara pembayaran.

Cara perusahaan memperkenalkan produk dan jasanya kepada konsumen adalah dengan promosi. Promosi diharapkan dapat meningkatkan penjualan dan perusahaan dapat mencapai tujuannya. Menurut Tjiptono (2008:219) promosi adalah sebagai salah satu cara untuk mendorong keberhasilan dan sukses nya pemasaran yang telah di rencanakan. Untuk itu sebagus dan sebaik apapun produk yang dihasilkan oleh perusahaan akan tetapi produk tersebut tidak dikenal dan diketahui oleh masyarakat maka mereka kemungkinan besar tidak akan tertarik untuk membelinya.

Sedangkan menurut Riyono dan Budiharja (2016:101) promosi merupakan kegiatan yang dilakukan oleh perusahaan untuk memperkenalkan suatu produk kepada masyarakat sehingga dapat menarik minat beli konsumen akan produk tersebut.

Dari beberapa pengertian promosi di atas, maka dapat disimpulkan bahwa promosi adalah salah satu unsur dari bauran pemasaran yang sangat berperan dalam memperkenalkan produk barang atau jasa dari perusahaan kepada konsumen, sehingga konsumen dapat mengenal dan dapat memutuskan untuk membeli produk barang atau jasa yang ditawarkan.

Secara umum bentuk-bentuk promosi memiliki fungsi yang sama, akan tetapi bentuk-bentuk tersebut dapat dibedakan berdasarkan tugas-tugas khususnya. Beberapa tugas tersebut atau yang dikenal dengan bauran promosi, menurut Kasmir (2012:59), : 
1. Periklanan (Advertising), Merupakan cara yang di gunakan untuk memberikan informasi dan menarik minat calon konsumen untuk membeli produk atau jasa.

2. Promosi Penjualan (Sales promotion), Promosi penjualan ini dilakukan untuk semakin menarik minat konsumen berkaitan dengan produk atau jasa yang di tawarkan. Hal ini dilakukan untuk semakin mempengaruhi keputusan konsumen dalam melakukan pembelian, oleh karena itu maka sebaiknya perusahaan harus melakukan rencana yang sangat matang untuk melakukan promosi agar dapat mempengaruhi konsumen.

3. Publisitas (publicity) adalah kegiatan promosi untuk memancing pelanggan melalui kegiatan seperti pameran, serta kegiatan lainnya. Kegiatan publisitas bertujuan untuk meningkatkan pamor perusahaan di mata para pelanggannya.

4. Penjualan Pribadi (Personal selling) adalah komunikasi langsung yang dilakukan oleh salesman atau salesgirl dan perusahaan. personal selling dilakukan oleh petugas costumer service atau service assistance yang dilakukan untuk memberikan informasi suatu produk kepada calon pelanggan pontensial dan membentuk pemahaman pelanggan terhadap produk sehingga mereka kemudian akan mencoba membelinya.

Adapun indikator yang di gunakan untuk mengukur variabel promosi dalam penelitian ini adalah menggunakan teori menurut Kasmir, (2012:59) : Periklanan (advertising), Sales Promotion, Publisitas dan Personal selling.

American Marketing Association dalam Kotler dan Keller (2009:258) menyatakan bahwa merek adalah suatu bentukn identitas dari suatu produk atau pun jasa dari sebuah perusahaan atau usaha dan membedakannya dari para pesaing. Sedangkan menurut Sunardi dan Primastiwi (2012:201) bahwa merek dapat ditunjukan dengan nama atau simbolsimbol tertentu, merek menyebabkan seseorang akan langsung teringat pada produk tersebut ketika ia membutuhkan produk yang serupa.

Perusahaan harus memutuskan bagaimana suatu merek dapat menerangkan sebuah nama merek pada produknya. Pemberian merek menurut Assauri (2010:206), memberikan manfaat bagi produsen yaitu sebagai berikut :

1. Untuk dasar melakukan indentifikasi, sehingga mudah dalam penanganan dan pencariannya.

2. Mencegah peniruan ciri khas dari suatu produk

3. Menunjukkan taraf mutu tertentu atas suatu produk yang ditawarkan.

4. Membantu mempermudah konsumen dalam pencarian produk yang terbukti memuaskan kebutuhan dan keinginannya.

5. Digunakan untuk membedakan harga dari produk-produk lainnya.

Citra merek yang baik akan mendorong untuk meningkatkan volume penjualan dan juga dapat meningkatkan citra dari sebuah perusahaan. Rangkuti menjelaskan (2008:3), citra merek merupakan sekumpulan asosiasi merek yang terbentuk dan melekat di benak konsumen.

Menurut pengertian citra merek tersebut, maka disimpulkan yaitu citra merek merupakan suatu anggapan yang tertanam lama pada pemikiran konsumen. Sehingga pemikiran tersebut tertanam menjadi sebuah persepsi pada masyarakat luas, persepsi tersebut berkembang membentuk image suatu produk atau jasa, yang pada akhirnya akan menciptakan kekuatan merek bagi produk atau jasa di mata konsumen.

Pada penelitian ini, menggunakan indikator citra merek yang dikemukakan 
Kerby dalam Sukma, Nurcahya dan Suryani (2016:4024), dimana citra merek memiliki empat elemen, yaitu:

1. Ketahanan

Yaitu berhubungan dengan kualitad dari sebuah merek produk atau jasa itu sendiri.

a. Produk atau jasa yang di jual atau di pasarkan, haruslah memenuhi standar yang di harapkan konsumen.

b. Pemilihan material untuk memproduksi produk harus sangat diperhatikan mutu dan standar nya. Hal ini dilakukan untuk selalu menjaga kualitas dari produk tersebut.

2. Kesesuaian

Hal ini berhubungan dengan keterkaitan dengan karakteristik produk dan citra merek dari produk yang ingin di bangun melalui sarana seperti :

a. Iklan, Promosi menggunakan media iklan harus memperhatikan hal-hal apa saja yang akan mengangkat nilai sebuah produk, sehingga dengan iklan tersebut dapat menjadikan dan memunculkan persepsi produk di mata konsumen, yang akan memacu minat beli konsumen terhadap produk.

b. Logo adalah merupakan identitas yang harus dimiliki produk. Logo yang baik mampu semakin memperkuat citra merek sebuah produk di mata konsumen.

\section{Keseksamaan}

Yaitu berkaitan dengan harapan sebesar apa sebuah citra merek ingin diciptakan, di mana hal ini berkaitan dengan :

a. Rasa, Jika sebuah produk berkaitan dengan rasa, maka tugas perusahaan adalah menjaga agar rasa tersebut tetap konsisten dan tidak berubah, bahkan mengusahakannya menjadi lebih baik lagi. Hal tersebut dilakukan untuk selalu menjaga kepercayaan konsumen dalam menggunakan produk, karena citra merek yang dikatakan baik adalah jika produk atau jasa tersebut bisa menciptakan pelanggan atau konsumen yang memiliki loyalitas yang tinggi terhadap produk mereka.

b. Harga, Merupakan salah satu hal terpenting yang juga dapat menarik minat konsumen. Perusahaan harus memperhatikan tingkatan harga di setiap outlet yang dimiliki, jangan sampai ada perbedaan harga yang signifikan. Sehingga pada akhir nya akan mempengaruhi harapan dan kepercayaan konsumen pada produk tersebut.

\section{Konotasi}

Adalah pendapat konsumen dari karakteristik produk yang mereka temui atau gunakan. Dari karakteristik tersebut konsumen dapat membedakan produk satu dengan produk - produk lainnya yang sejenis, sehingga pada akhirnya lebih memilih yang mereka anggap baik dari salah satu produk tersebut. Pilihan tersebut dapat dilihat berdasarkan :

a. Variasi rasa / produk, Ragam produk yang ada dapat memenuhi dan menyesuaikan dengan selera dan pilihan konsumen, sehingga sesuai dengan kebutuhan konsumen.

b. Pelayanan, Pelayanan yang baik dan memuaskan hati konsumen akan menghasilkan persepsi yang baik pula untuk sebuah produk. Hal tersebut tentunya juga akan mempengaruhi citra merek dari produk tersebut.

\section{METODE}

Penelitian ini dilakukan pada PT Capella Dinamik Nusantara Pekanbaru. Adapun yang menjadi populasi pada penelitian ini adalah semua konsumen yang melakukan pembelian sepeda motor Honda pada PT Capella Dinamik Nusantara Pekanbaru, yaitu sebanyak 19.853 orang. Karena keterbatasan waktu, maka penulis mengambil sampel dengan menggunakan rumus Slovin ( Sanusi, 2011:101). 
Setelah ditentukan 100 responden, karena jumlah sampel minimal yang dibutuhkan sudah didapatkan, maka dalam penelitian ini teknik penarikan sampel yang digunakan adalah teknik insidental sampling. Menurut Sugiyono (2008 : 156), insidental sampling adalah teknik penentuan sampel berdasarkan kebetulan, yaitu siapa saja yang secara kebetulan bertemu dengan peneliti dapat digunakan sebagai sampel, bila dipandang orang yang kebetulan ditemui itu cocok sebagai sumber data.

Uji validitas merupakan suatu alat ukur tes dalam kuesioner, Sunyoto (2014). Pengujian validitas dengan menggunakan $\alpha=$ $0,05(5 \%)$ diketahui $r_{\text {hitung }}>r_{\text {tabel }}$. Dan apabila $\mathrm{r}_{\text {hitung }}<\mathrm{r}_{\text {tabel }}$ maka status kuesioner atau angket dinyatakan gugur. Dalam penelitian ini, pengujian validitas dilakukan dengan menggunakan bantuan SPSS 16.

Menurut Sugiyono (2008 : 172), uji reliabilitas digunakan untuk mengetahui apakah alat pengumpul data menunjukkan tingkat ketepatan, tingkat keakuratan, kestabilan atau konsisten dalam mengungkapkan gejala tertentu. Syarat dalam uji reliabilitas ini adalah, jika nilai koefisien cronbach's alpha besar dari 0,6 maka instrumen penelitian tersebut dikatakan reliable.

Uji Hipotesis, Pengujian hipotesis uji simultan (uji F), yaitu untuk melihat signifikansi secara bersama - sama variabel bebas terhadap variabel terikat, Uji parsial (uji t) untuk melihat pengaruh secara sendiri -sendiri masing-masing variabel bebasnya terhadap variabel terikat. Uji koefisien determinasi digunakan untuk mengetahui persentase sumbangan pengaruh variabel independen $(\mathrm{X})$, terhadap variabel dependen (Y). Koefisien ini menunjukkan seberapa besar persentase variasi variabel independen yang digunakan dalam model dan mampu menjelaskan variasi variabel dependen.

\section{HASIL}

Berdasarkan hasil uji validitas yang telah dilakukan dalam penelitian ini, maka di peroleh nilai korelasi terendah sebesar 0,516 dan tertinggi 0,907, maka seluruh item pernyataan yang di uji pada penelitian ini dikatakan layak untuk di uji, karena sesuai dengan persyaratan uji validitas di atas yaitu seluruh $\mathrm{r}$ hitung $>$ dari $\mathrm{r}$ tabel, dengan $\mathrm{r}$ tabel pada penelitian ini sebesar 0,16 .

Hasil pengujian reliabilitas dalam penelitian ini memperoleh hasil cronbach's alpha untuk promosi yaitu sebesar 0,728 , citra merek 0,832 , dan keputusan pembelian 0,812 , oleh karena itu maka nilai alpha keseluruhan dalam penelitian ini dikatakan reliable, karena nilai alpha pada penelitian ini besar dari 0,6.

Hasil Pengujian Hipotesis Secara Simultan Tabel Uji Hipotesis Secara Simultan

ANOVA $^{b}$

\begin{tabular}{|l|r|r|r|r|r|}
\hline Model & $\begin{array}{c}\text { Sum of } \\
\text { Squares }\end{array}$ & df & $\begin{array}{c}\text { Mean } \\
\text { Square }\end{array}$ & $\mathrm{F}$ & Sig. \\
\hline $1 \quad \begin{array}{l}\text { Regres } \\
\text { sion }\end{array}$ & 780.958 & 2 & 390.479 & 46.42 & 9 \\
$\begin{array}{l}\text { Residu } \\
\text { al } \\
\text { Total }\end{array}$ & $\begin{array}{r}815.802 \\
1596.76\end{array}$ & 97 & 8.410 & & \\
0 & 99 & & & \\
\hline
\end{tabular}

Hasil perhitungan uji hipotesis secara simultan didapatkan nilai $\mathrm{F}$ hitung sebesar 46.429. Adapun nilai $\mathrm{F}$ tabel adalah sebesar 2,70, sehingga dapat dikatakan bahwa $\mathrm{F}$ hitung > dari $\mathrm{F}$ tabel, ini berarti bahwa secara bersama-sama variabel Promosi (X1) dan Citra Merek (X2) berpengaruh signifikan terhadap variabel Keputusan Pembelian (Y). Dengan kata lain jika promosi dan citra merek ditingkatkan secara bersama-sama maka akan berdampak terhadap peningkatan keputusan pembelian dari sepeda motor merek Honda pada PT Capella Dinamik Nusantara di Pekanbaru.

Hasil Pengujian Hipotesis Secara Parsial Tabel Uji Hipotesis Secara Parsial

$$
\text { Coefficients }^{a}
$$

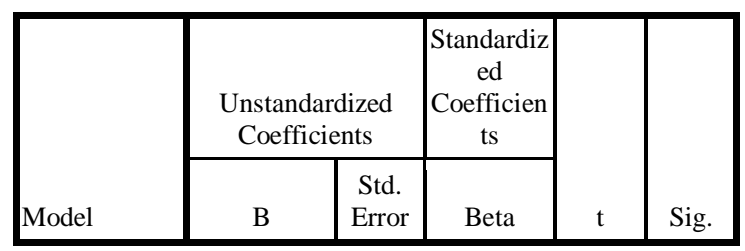

p.ISSN: $2407-800 \mathrm{X}$ e.ISSN: $2541-4356$ 


\begin{tabular}{|ll|r|r|r|r|r|}
\hline 1 & (Consta & 7.503 & 3.795 & & 1.977 & .051 \\
$\mathrm{nt})$ & .262 & .114 & .181 & 2.303 & .023 \\
$\mathrm{X} 1$ & .787 & .102 & .609 & 7.742 & .000 \\
$\mathrm{X} 2$ & &
\end{tabular}

Pada pengujian hipotesis secara parsial, didapatkan nilai $\mathrm{t}$ hitung variabel Promosi (X1) sebesar 2,303>1,660 (t tabel), ini berarti bahwa variabel promosi memiliki pengaruh secara parsial terhadap keputusaan pembelian sepeda motor merek Honda pada PT Capella Dinamik Nusantara di Pekanbaru. Demikian juga untuk uji parsial variabel Citra Merek (X2), diperoleh t hitung sebesar 7,742>1,660 (t tabel), ini berarti bahwa variabel Citra Merek juga berpengaruh secara parsial terhadap keputusaan pembelian sepeda motor merek Honda pada PT Capella Dinamik Nusantara di Pekanbaru.

Hasil Pengujian Koefisien Determinasi Tabel Uji Koefisien Determinasi Model Summary

\begin{tabular}{|l|l|l|l|l|}
\hline $\begin{array}{l}\text { Mod } \\
\text { el }\end{array}$ & $R$ & $\begin{array}{l}\text { R } \\
\text { Square }\end{array}$ & $\begin{array}{l}\text { Adjusted } \\
\text { R Square }\end{array}$ & $\begin{array}{l}\text { Std. Error } \\
\text { of the } \\
\text { Estimate }\end{array}$ \\
\hline 1 & $.699^{\mathrm{a}}$ & .489 & .479 & 2.90006 \\
\hline
\end{tabular}

Untuk nilai R Square di dapatkan nilai sebesar 0,489 atau 49\%, artinya adalah bahwa sebesar $49 \%$ variabel keputusan pembelian (Y) di pengaruhi oleh Promosi (X1) dan Citra Merek (X2), sedangkan sisanya sebesar $51 \%$ keputusan pembelian pada PT Capella Dinamik Nusantara dipengaruhi oleh variabel lain yang tidak diteliti dalam penelitian ini.

\section{PEMBAHASAN}

Pada penelitian ini dapat dilihat bahwa variabel promosi dan citra merek secara bersama - samaber pengaruh signifikan terhadap keputusan pembelian sepeda motor merek Honda pada PT. Capella Dinamik Nusantara Pekanbaru. Hal ini dapat diartikan bahwa peningkatan variabel
Promosi dan citra merek secara bersamasama akan mempengaruhi tingkat pembelian dari sepeda motor merek Honda pada PT. Capella Dinamik Nusantara Pekanbaru.

Dari hasil penelitian dapat di lihat bahwa pengaruh promosi terhadap keputusan pembelian memperoleh hasil yang positif dan signifikan. Hasil yang positif tersebut memberikan arti yang menunjukkan bahwa setiap terjadinya peningkatan promosi maka akan mempengaruhi tingkat keputusan pembelian konsumen terhadap sepeda motor merek Honda pada PT. Capella Dinamik Nusantara Pekanbaru.

Berdasarkan hasil dari penelitian ini, maka dapat di lihat bahwa variabel citra merek berpengaruh secara parsial terhadap variabel keputusan pembelian sepeda motor merek Honda pada PT. Capella Dinamik Nusantara Pekanbaru. Hal ini menunjukkan bahwa pengaruh citra merek yang tinggi dapat mempengaruhi konsumen dalam memutuskan pembelian sepeda motor merek Honda pada PT. Capella Dinamik Nusantara Pekanbaru.

\section{SIMPULAN}

1. Variabel promosi dan variabel Citra Merek berpengaruh secara simultan terhadap keputusan pembelian konsumen sepeda motor merek Honda pada PT Capella Dinamik Nusantara Pekanbaru.

2. Variabel promosi berpengaruh signifikan terhadap variabel keputusan pembelian konsumen sepeda motor merek Honda pada PT Capella Dinamik Nusantara Pekanbaru.

3. Variabel Citra Merek berpengaruh signifikan terhadap variabel Vkeputusan pembelian konsumen sepeda motor merek Honda pada PT Capella Dinamik Nusantara Pekanbaru.

4. Variabel promosi memiliki pengaruh yang lebih besar terhadap variabel keputusan pembelian 
konsumen sepeda motor merek Honda pada PT Capella Dinamik Nusantara Pekanbaru.

\section{DAFTAR RUJUKAN}

Assauri, Softjan. 2010. Manajemen Pemasaran Dasar Konsep dan Strategi. Penerbit Rajagrafindo Persada. Jakarta

Azwar, Saifuddin. 2010. Metode Penelitian. Penerbit Pustaka Pelajar.Yogyakarta.

Hurriyati, Ratih, 2015, Bauran Pemasaran dan Loyalitas Konsumen, Cetakan Keempat, Penerbit Alfabeta, Bandung.

Joe, Kent Kerby.2010.Esensi dalam Manajemen Pemasaran. Diterjemahkan Oleh : Sandy. Alfabeta. Bandung.

Kasmir, 2008, Pemasaran Bank, Kencana, Jakarta.

Kotler, Philip \& Kevin Lane Keller, 2009, Manajemen Pemasaran, edisi 12, Jilid 1, Cetakan Keempat, Penerbit Indeks. Jakarta.

Rangkuti, Freddy, 2008, The Power of Brands, Cetakan Ketiga, Jakarta, Penerbit Gramedia Pustaka Utama.

Riduwan dan Sunarto, 2014, Pengantar statistika untuk Penelitian pendidikan, sosial, komunikasi, ekonomi dan bisnis. Cetakan ke 7. Penerbit Alfabeta. Bandung.

Riyono dan Budiharja, Gigih Erlik, 2016, Pengaruh Kualitas Produk, Harga, Promosi dan Brand Image Terhadap Keputusan Pembelian Produk Aqua di Pati, Jurnal STIE Semarang, Vol 8 Nomor 2, Juni.

Sangadji, Etta Mamang \& Sopiah, 2013, Perilaku Toko Pendekatan Praktis disertai Himpunan Jurnal Penelitian, Yogyakarta, Penerbit ANDI.
Sanusi, Anwar, 2011, Metodologi Penelitian Bisnis, Penerbit Salemba Empat, Jakarta Selatan.

Sugiyono, 2008, Metode Penelitian kuantitatif Kualitatif dan R\&D., Alfabet, Bandung.

Sukma, Kadek Ayu Dwi Sudias Kumala, Ketut Nurcahya dan Alit Suryani, 2016, Pengaruh Celebrity Endorser, Brand Image dan Kepercayaan terhadap keputusan pembelian produk pembersih wajah Mens Biore, Jurnal Manajamen Unud, Vol.5, No.7 : 4016-4043.

Sunardi dan Anita Primastiwi, 2012, Bisnis Pengantar:Konsep, Strategi dan Kasus, Yogyakarta, Penerbit Caps.

Sunyoto, Danang., 2014., Praktik Riset Perilaku Konsumen (Teori, Kuesioner, Alat, dan Analisis Data)., CAPS., Yogyakarta.

Tjiptono, Fandy, 2011, Manajemen dan Strategi Merek, Yogyakarta, Penerbit Andi Offset. 